\title{
REPRESIVNE MJERE NJEMAČKE VOJSKE U BOSNI I HERCEGOVINI TIJEKOM DRUGOG SVJETSKOG RATA
}

\author{
Nikica Barić \\ Hrvatski institut za povijest \\ nbaric@isp.hr
}

\begin{abstract}
Apstrakt: U članku su prikazane represivne mjere koje je njemačka vojska tijekom Drugoga svjetskoga rata primjenjivala na području Bosne i Hercegovine. U tom je razdoblju Bosna i Hercegovina bila u sastavu Nezavisne Države Hrvatske (NDH). Istovremeno je upravo Bosna i Hercegovina tijekom rata bilo ključno područje djelovanja Narodnooslobodilačkog, odnosno partizanskog pokreta. Članak prikazuje kako je, postupno, njemačka vojska u NDH preuzimala sve veće ovlasti u borbi protiv partizana, podređujući sebi snage NDH i njezine civilne vlasti i koje je represivne mjere primjenjivala protiv partizana, ali i protiv stanovništva.
\end{abstract}

Ključne riječi: Drugi svjetski rat, Bosna i Hercegovina, Nezavisna Država Hrvatska, njemačka vojska, represivne mjere

\begin{abstract}
The paper presents the main elements of repressive measures used by the German Wehrmacht in Bosnia and Herzegovina during World War II. In that period, Bosnia and Herzegovina was part of the Independent State of Croatia (Nezavisna Država Hrvatska, NDH). Bosnia and Herzegovina soon became the main area of operations of the People's Liberation Movement led by the Communist Party of Yugoslavia and its Partisan units. As NDH troops became unable to suppress the uprising, the Wehrmacht gradually took the increasing role and ultimately gained command and control over NDH troops and civilian authorities. In order to destroy the People's Liberation Movement, Germans used a variety of repressive measures.
\end{abstract}


Key words: World War II, Bosnia and Herzegovina, Independent State of Croatia, Wehrmacht, repressive measures

Nakon proglašenja Nezavisne Države Hrvatske (NDH), Njemačka nije namjeravala na njezinom teritoriju držati veće vojne snage. Kao njemački vojni predstavnik u Zagrebu je postavljen general Edmund Glaise von Horstenau. Na području NDH bila je razmještena njemačka 718. pješačka divizija i neke manje jedinice. ${ }^{1}$

No, vlasti NDH, odnosno ustaški režim, poveli su politiku zatiranja nacionalnog identiteta srpskog stanovništva, koje je bilo izloženo različitim oblicima državnog terora i masovnog ubijanja. ${ }^{2}$ Posljedica takvih postupaka bio je ustanak srpskog stanovništva, među ostalim upravo u Bosni i Hercegovini. Ustanici će se postupno razviti u dva međusobno suprotstavljena pokreta - Narodnooslobodilački pokret pod vodstvom Komunističke partije Jugoslavije i četnički pokret. Pri tome će četnici postupno uspostaviti suradnju s talijanskom, a zatim i s njemačkom vojskom, a u nekim slučajevima is vlastima $\mathrm{NDH} .{ }^{3}$

NDH je bila podijeljena njemačko-talijanskom demarkacijskom linijom, koja je u njemačkom interesnom području ostavila i sjeverne dijelove Bosne i Hercegovine (Banja Luka, Tuzla, Sarajevo). Budući da NDH sa svojim snagama nije bila u stanju suzbiti ustanički pokret, tijekom prve polovine 1942. njemačka vojska uključila se u suzbijanje ustanika u istočnoj Bosni, a u ljeto iste godine pod njemačkim zapovjedništvom provedena je velika operacija protiv partizana u Bosanskoj krajini (Kozara). No, sredinom

* Ovaj članak nastao je u sklopu projekta: "Rat, žrtve, nasilje i granice slobode u hrvatskoj povijesti 20. stoljeća” (IP-2019-04-6673) Hrvatskoga instituta za povijest koji financira Hrvatska zaklada za znanost.

${ }^{1}$ Nikica Barić, Ustroj kopnene vojske domobranstva Nezavisne Države Hrvatske, 1941.-1945, Zagreb: Hrvatski institut za povijest, 2003, 284-287.

${ }^{2}$ Tomislav Dulić, Utopias of Nation, Local Mass Killing in Bosnia and Herzegovina, 1941-1942, Uppsala: Acta Universitatis Upsaliensis, 2005.

${ }^{3}$ Opširno o tome vidi: Rasim Hurem, Bosna i Hercegovina u Drugom svjetskom ratu 1941-1945, Zagreb-Sarajevo: Plejada - Bošnjačka nacionalna zajednica za Zagreb i Zagrebačku županiju University Press, 2016. 
1942. uslijedio je pohod partizanskih proleterskih brigada, odnosno grupe brigada s kojima se nalazio partizanski Vrhovni štab na čelu s Josipom Brozom Titom. Te partizanske snage su s područja Zelengore krenule u prodor prema zapadu, prema Bosanskoj krajini. One su stupile u vezu s partizanima u Bosanskoj Krajini, Dalmaciji i Hrvatskoj, čime je dan poticaj daljnjem jačanju partizana na navedenim područjima. Pohodom proleterskih brigada znatni dijelovi Bosne došli su pod nadzor partizana, koji su početkom novembra 1942. zauzeli i Bihać. To područje pod nadzorom partizana Nijemci su nazivali "Titovom državom”. Zato su prema kraju 1942. u Berlinu odlučili poduzeti opširne mjere, kako bi se suzbio partizanski pokret, koji je snažno uporište imao upravo u Bosni i Hercegovini. Ovo je bilo uvjetovano i širim i za Nijemce nepovoljnim razvojem stanja na Sredozemlju, odnosno, njihovim porazima u sjevernoj Africi, zbog čega je na Balkanu trebalo suzbiti ustanički pokret, kako on ne bi surađivao sa zapadnim saveznicima u slučaju njihovog iskrcavanja na tom području. Osim toga, Nijemci su težili iskoristiti bosansko-hercegovačke sirovine (boksit, drvna građa, željezna ruda), te je i navedeno bio razlog da suzbiju partizane na tom području. Zato su Nijemci, zajedno s Talijanima i snagama NDH, početkom 1943. pokrenuli operaciju "Weiss", usmjerenu na uništenje "Titove države". ${ }^{4}$ Unatoč toj i kasnijim operacijama koje su Nijemci provodili na području Bosne i Hercegovine, oni nisu uspjeli uništiti partizanski pokret na tom području.

Tako su krajem 1942. i početkom 1943. Nijemci proveli reorganizaciju svojih zapovjedništava na području $\mathrm{NDH}$, a ona su zadobila nove ovlasti. General Glaise von Horstenau postao je njemački opunomoćeni general u Hrvatskoj, a general Rudolf Lüters imenovan je za zapovjednika njemačkih trupa u Hrvatskoj. Tijekom 1942. NDH je određivala opunomoćenike koji su, na određenom području, trebali koordinirati djelovanje njezinih

\footnotetext{
${ }^{4}$ Opširno o tome vidi: Rafael Brčić, "Njemački i italijanski planovi u Bosni i Hercegovini u svjetlu dokumenata (1942-1943)", u: AVNOJ i Narodnooslobodilačka borba u Bosni i Hercegovini (19421943), Materijali sa naučnog skupa održanog u Sarajevu 22. i 23. novembra 1973. godine, ur. Dušan Papadopolos, Beograd: “Rad”, 1974, 131-155; Рафаел Брчић, “Основна обиљежја корекције њемачко-усташке политике према Србима у “Независној Држави Хрватској”, и: Прилози, Година XI-XII, Број 11-12, Сарајево: Институт за историју, 1975-1976, 177-206.
} 
vlasti s operacijama njemačke vojske. NDH je 18. januara 1943. donijela i Zakonsku odredbu o iznimnom stanju kojom je definirano djelovanje "glavara građanske uprave”. Bila je riječ o funkcionerima NDH zaduženima za vođenje uprave na određenom dijelu teritorije, a istovremeno su oni trebali voditi brigu da uprava NDH izvršava naredbe njemačke vojske. Osim što su ovime civilne vlasti NDH morale, preko glavara građanske uprave, djelovati u skladu s njemačkim zahtjevima, također je njemačka vojska preuzela operativno zapovjedništvo nad snagama NDH, odnosno domobranskim i ustaškim jedinicama. ${ }^{5}$

U ljeto 1943. došlo je do nove promjene u njemačkom sistemu zapovijedanja. Tada je ukinuto Zapovjedništvo njemačkih trupa u Hrvatskoj, a zapovjedništvo nad svim njemačkim jedinicama u NDH preuzelo je Zapovjedništvo njemačke 2. oklopne armije, na čelu s generalom Lotharom Rendulicem, čije se sjedište nalazilo u Srbiji. ${ }^{6}$

Osim toga, Nijemci su vojne obveznike NDH počeli izdvajati za formiranje novih divizija njemačke vojske (takozvane "legionarske" divizije). Pripadnici njemačke manjine u NDH iskorišteni su za popunjavanje SS-divizije "Prinz Eugen", a kasnije je dosta bosanskohercegovačkih Muslimana uključeno u SS-diviziju "Handžar". Uz sve navedeno, tijekom 1943. godine Nijemci su na teritoriju NDH formirali i svoju policijsku organizaciju s posebnim jedinicama koje su znatnim dijelom bile popunjene vojnim obveznicima $\mathrm{NDH}{ }^{7}$

U ovom ću prilogu u glavnim crtama prikazati koje je represivne mjere njemačka vojska na području Bosne i Hercegovine primjenjivala za suzbijanje Narodnooslobodilačkog pokreta, kako je pri tome postupala sa zarobljenim partizanima i prema stanovništvu, kao i kako je navedeno utjecalo na odnose njemačke vojske s vlastima $\mathrm{NDH}{ }^{8}$

\footnotetext{
${ }^{5}$ N. Barić, Ustroj kopnene vojske domobranstva NDH, 287-292.

${ }^{6}$ Isto, 292-293.

${ }^{7}$ Isto, 295-301.

${ }^{8} \mathrm{O}$ represivnim mjerama njemačke vojske u NDH postoje određeni prilozi. Primjerice vidi: Jonathan E. Gumz, "Wehrmacht Perceptions of Mass Violence in Croatia, 1941-1942", The Historical
} 


\section{Represivne mjere njemačke vojske tijekom 1942. godine}

Počekom januara 1942, Zapovjedništvo njemačke 342. pješačke divizije, koja je trebala sudjelovati u operaciji protiv ustanika u istočnoj Bosni, morala je svojim pripadnicima objasniti kako će na tom području postupati s neprijateljem i stanovništvom. Nesumnjivo je ovo bilo potrebno zato što je spomenuta divizija nedugo prije stigla iz Francuske (a vrlo brzo će biti upućena na bojište u Sovjetski Savez). Predviđeno je da jedinicama te divizije kao vodiči budu dodijeljeni predstavnici vlasti NDH. Zapovjedništvo divizije objasnilo je da su protivnici četnici i komunisti i svi koji im pružaju potporu. Predviđeno je da se zarobljene komuniste i druge koji pružaju otpor, kao i one koji bježe pred njemačkim snagama, ili služe protivniku kao obavještajci, nakon kratkog saslušanja strijelja. Ovo je trebalo primijeniti i na žene i djecu koji su sudjelovali u borbama. Dio zarobljenika trebalo je iskoristiti i kao nosače za potrebe njemačke vojske. Kuće iz kojih se pružao otpor trebalo je spaliti. ${ }^{9}$

Nedugo kasnije u Beogradu je održan sastanak kod njemačkog generala Paula Badera. On je bio opunomoćeni zapovijedajući general u Srbiji, ali je bio nadležan i za operacije koje su njemačke snage provodile u NDH. Bader je na tom sastanku s funkcionerima NDH i njemačkim predstavnicima u Zagrebu dogovarao predstojeće operacije protiv ustanika u istočnoj Bosni. General Bader tom je prilikom zaključio da se njemačka vojska tijekom tih operacija ne može opterećivati postupkom sa stanovništvom i pretresom terena, te bi navedeno trebale preuzeti vlasti NDH. Nijemci će protivnikom smatrati one koje zateknu naoružane, kao i sumnjive osobe. Bilo je očito da će Nijemci tako definirane protivnike strijeljati. ${ }^{10}$

Journal, Cambridge, Volume 44, 4 (December 2001), 1015-1038.; Klaus Schmider, "Auf Umwegen zum Vernichtungskrieg? Der Partisanenkrieg in Jugoslawien, 1941-1944., u: Die Wehrmacht, Mythos und Realität, Im Auftrag des Militärgeschichtlichen Forschungsamtes herausgegeben von Rolf-Dieter Müller und Hans-Erich Volkmann, München: R. Oldenbourg Verlag, 1999, 901-922. ${ }^{9}$ Zbornik dokumenata i podataka o Narodnooslobodilačkom ratu naroda Jugoslavije, Tom XII, Knjiga 2, Dokumenti Nemačkog Rajha 1942, Beograd: Vojnoistorijski institut, 1976, dok. br. 3.

${ }^{10}$ Isto, dok. br. 4. 
Krajem januara 1942. general Bader odredio je da područje istočne Bosne (prostor omeđen rijekama Bosnom, Drinom i Savom, a na jugu njemačko-talijanskom demarkacijskom linijom koja je prolazila kroz NDH) postaje operativno područje njemačke 718. pješačke divizije u Sarajevu, te su na tom području sve domobranske i ustaške snage u operativnom smislu podređene toj njemačkoj diviziji. ${ }^{11}$ Zapovjedništvo 718 . divizije je u junu 1942. odredilo postupanje s ustanicima na njezinom operativnom području. Tako je ponovljeno da, kao i prethodno, vrijedi odredba generala Badera da se osobe koje neovlašteno nose oružje trebaju kazniti smrću. Zato je i dalje na snazi bila prethodna zapovijed 718. divizije da se osobe koje se tijekom borbe zarobi s oružjem treba strijeljati, a isto je trebalo postupiti i s onima kod kojih se pronađe skriveno oružje. Sumnjive osobe trebalo je otpremiti u zarobljenički logor 718. divizije, ali nije navedeno kakav je zatim s njima trebao biti postupak. Nasuprot navedenom - osobe koje se dobrovoljno predaju s oružjem trebalo je razoružati i pustiti na slobodu. ${ }^{12}$

Sredinom 1942. njemački general Friedrich Stahl je, kao zapovjednik Borbene skupine “Zapadna Bosna”, u čijem su sastavu, osim njemačkih, bile i brojne snage NDH, proveo veliku ofenzivu protiv partizana na Kozari. I, tom prilikom naredba je bila da se strijelja zarobljene partizane i one koji im pomažu. Tako je strijeljano na stotine partizana, ali i civila, a dio je, nakon završetka operacije na Kozari, upućen na (prisilni) rad u Njemačku i Norvešku. ${ }^{13}$

\section{Smjernice njemačke vojske za represivne mjere iz januara 1943. godine}

Početkom 1943. Nijemci su, s NDH i Talijanima, pripremali provođenje velikih operacija protiv partizana na području Bosne i Hercegovine.

\footnotetext{
${ }^{11}$ Hrvatski državni arhiv u Zagrebu (HR-HDA), 1198, Oružničko krilno zapovjedništvo Bileća, Taj. Broj: 364/1942.

${ }^{12}$ HR-HDA-1450, Zbirka mikrofilmova gradiva iz inozemnih arhiva koje se odnosi na Hrvatsku, rola D-2129, snimka 344, Predmet: Postupak sa pobunjenicima istočno od Sarajeva. Prijepis.

${ }^{13}$ Opširnije o tome vidi: Nikica Barić, "Kozara 1942. - sudbina zarobljenika, civila i djece”, u: Pilar, Časopis za društvene i humanističke studije, br. 22(2), Zagreb: Institut društvenih znanosti Ivo Pilar, 2016, 53-111.
} 
Bila je riječ o spomenutoj operaciji "Weiss" usmjerenoj protiv partizanske "Bihaćke republike". Istovremeno je to bilo razdoblje u kojem je njemačka vojska, kako sam prethodno opisao, reorganizirala svoj sistem zapovijedanja u NDH i preuzela puno veće ovlasti u djelovanju na njezinom teritoriju.

U tim okolnostima general Rudolf Lüters, koji je nedugo prije postavljen za zapovjednika njemačkih trupa u Hrvatskoj, izdao je 12. januara 1943. zapovijed o načinu vođenja borbe na teritoriji NDH. U njoj je objasnio da treba surađivati s vlastima $\mathrm{NDH}$, ali isto tako na operativnom području njemačka vojske, njezine potrebe, ako je to nužno, dolaze prije suvereniteta NDH. ${ }^{14}$

Lüters je objasnio da su opravdane sve mjere koje su nužne za osiguranje njemačkih snaga i za pacifikaciju stanja, pa zato niti jedan njemački vojnik ne može biti pozvan na odgovornost zbog preoštrog postupanja. Pri ovome, ipak, nisu bili dopušteni nečasni postupci poput pljačke i prijestupa prema ženama i djeci i takva je djela trebalo oštro kazniti. ${ }^{15}$

Lüters je odredio da treba objesiti ili strijeljati sve koji su sudjelovali u borbama protiv njemačke vojske i NDH. Sumnjive osobe trebalo je uhapsiti i dijelom upotrijebiti za razmjenu zarobljenika s partizanima, a ostale iskoristiti kao taoce pri provođenju odmazdi. ${ }^{16}$

Lüters je također odredio da treba razoriti partizanska uporišta i objekte koji im mogu poslužiti kao skloništa, a na isti je način trebalo postupiti i s naseljenim mjestima iz kojih je otvarana paljba na njemačke snage. Također je, ako to bude naređeno od nadležnog zapovjednika divizije, određena naselja trebalo razoriti za odmazdu. ${ }^{17}$

Župska redarstvena oblast u Sarajevu je nedugo kasnije izvijestila da je 16. januara 1943. u tom gradu istaknut proglas generala Lütersa. U njemu je navedeno da je cijelo područje Bosne (s iznimkom onih dijelova na

\footnotetext{
${ }^{14}$ Zbornik dokumenata i podataka o Narodnooslobodilačkom ratu jugoslovenskih naroda, Tom IV, Knjiga 9, Borbe u Bosni i Hercegovini 1943 god, Beograd: Vojnoizdavački zavod "Vojno delo", 1954, dok. br. 215.

${ }^{15}$ Isto.

${ }^{16}$ Isto.

${ }^{17}$ Isto.
} 
kojima je bila smještena talijanska vojska) operativno područje njemačke vojske. U skladu s time svatko tko sudjeluje u borbi protiv njemačke vojske i NDH, ili tu borbu pomaže, kao i svatko tko neovlašteno posjeduje oružje, bit će kažnjen smrću "bez sudskog postupka”. Općine koje pomažu partizane i kuće u kojima bude pronađeno oružje bit će uništene. Također je istaknuto da, ako to zahtijevaju prilike, naredbe koje izdaje njemačka vojska vrijede "prije svakog ostalog prava". 18

\section{Predstavnici NDH pri njemačkim zapovjedništvima}

U opisanim okolnostima, u kojima je NDH prepustila Nijemcima velike ovlasti za djelovanje, njezine vlasti ipak su težile zaštititi vlastite interese.

Dr. Pavao Canki, opunomoćenik Vlade NDH u Sarajevu, obratio se 12. februara 1943. vlastima u Zagrebu. On je očito tražio da se njemačkim jedinicama dodijeli predstavnike vlasti NDH, kako bi se izbjeglo da u njemačkim operacijama stradaju dijelovi stanovništva koje su te vlasti smatrale lojalnima. Ubrzo je Predsjedništvo vlade NDH odgovorilo da je Ante Pavelić odlučio Cankiju dati ovlasti za organizaciju "naših vodiča" kod Nijemaca, za “očuvanje našega življa na terenu”. Za te potrebe Canki je mogao angažirati službenike iz bilo kojega resora, pa i sudce koji nisu nužni za svoju službu. ${ }^{19}$

Ante Pavelić je 20. maja 1943. odredio da državni ministar Mladen Lorković preuzme sve poslove oko njemačke vojske u NDH. Lorković je trebao raditi na određivanju smjernica za suradnju vlasti NDH s Nijemcima. U suradnji s ministarstvima oružanih snaga, unutarnjih poslova i vanjskih poslova, trebao je sklapati i provoditi sporazume o suradnji između vlasti NDH i njemačke vojske. Osim toga, on je trebao voditi osobne i stvarne poslove glavara građanske uprave i posebnih opunomoćenika Vlade NDH, u smislu Zakonske odredbe o iznimnom stanju od 18. januara 1943. godine.

\footnotetext{
${ }^{18}$ Isto, dok. br. 185.

${ }^{19}$ Državni arhiv u Karlovcu (HR-DAKA), 348, Zbirka preslika iz Arhiva oružanih snaga (Vojno-istorijski institut) u Beogradu, NDH, Razdjel financijalne straže Pribanjci, Broj: 31/1943.
} 
Ured ministra Lorkovića radio je u Predsjedništvu vlade NDH. ${ }^{20}$

Tijekom septembra 1943. Pavelić je s generalom Glaise von Horstenauom i njemačkim poslanikom u NDH, Siegfriedom Kascheom dogovorio način na koji će glavari građanske uprave (među kojima i Ivica Frković sa sjedištem u Sarajevu i Aleksandar Benak sa sjedištem u Banja Luci) i opunomoćenici Vlade NDH pri njemačkim jedinicama surađivati s njemačkim zapovjednicima. Istovremeno su svi ovi predstavnici NDH bili podređeni ministru Lorkoviću, koji je sva pitanja povezana s njemačkom vojskom trebao, na najvišem nivou, rješavati s generalom Glaise von Horstenauom. ${ }^{21}$

Ministar Mladen Lorković je bio zadužen za poslove povezane s njemačkom vojskom do pred kraj 1943. godine. Nakon toga, ove poslove preuzeo je Ured pomoćnika ministra unutarnjih poslova na čijem se čelu nalazio državni ministar Vjekoslav Vrančić. ${ }^{22}$ Ovo je trajalo do početka maja 1944, kada je Ured pomoćnika ministra unutarnjih poslova trebao prestati djelovati. Nakon toga su vlasti NDH sve dopise o problemima u odnosima s njemačkom vojskom trebale slati Uredu ministra unutarnjih poslova $\mathrm{NDH} .{ }^{23}$

Osim toga, nedugo kasnije, odnosno 19. maja 1944, Predsjedništvo vlade NDH je donijelo naredbu o djelatnosti izaslanika Vlade NDH pri njemačkim vojnim zapovjedništvima. Tom naredbom navedena djelatnost trebala je biti usklađena, a ona je donesena u sporazumu s Vrhovnim zapovjedništvom njemačkih oružanih snaga na Balkanu. Tako je određeno da pri zapovjedništvima njemačkih divizija djeluju "časnici za vezu", pri zapovjedništvima njemačkih armijskih korpusa trebali su djelovati "pouzdanici”, a pri Zapovjedništvu njemačke 2. oklopne armije trebao je djelovati “opunomoćenik" Vlade NDH. Predstavnici NDH pri divizijama bili su podređeni onima pri korpusima, a oni su opet bili podređeni predstavniku pri Zapovjedništvu 2. oklopne armije. ${ }^{24}$

\footnotetext{
${ }^{20}$ HR-HDA-217, Ministarstvo narodnog gospodarstva NDH, Ured ministra, Broj: 814-M-1943.

${ }^{21}$ Bogdan Krizman, Ustaše i Treći Reich, Prvi svezak, Zagreb: Globus, 1983, 126-127.

${ }^{22}$ HR-HDA-223, Ministarstvo unutarnjih poslova NDH, U. P. M. Taj. Broj: 587/1943.

${ }^{23}$ HR-HDA-223, U. P. M. Taj. Broj: 2285/1944.

${ }^{24}$ HR-HDA-216, Ministarstvo narodne prosvjete NDH, Ured ministra, Taj. Broj: 2767/1944.
} 
Nekoliko mjeseci kasnije, početkom decembra 1944, Predsjedništvo vlade NDH je, ponovno u dogovoru s Nijemcima, izdalo novu naredbu koja je trebala osigurati usklađeni rad predstavnika Vlade NDH pri njemačkim zapovjedništvima. Oni su pri provođenju vojnih operacija morali štititi interese hrvatskog naroda i trebali su stajati na raspolaganju njemačkim zapovjedništvima kao organi za vezu s vlastima NDH. U slučaju potrebe trebali su, na njemačkih zahtjev, osigurati da te vlasti provedu određene neodgodive mjere. ${ }^{25}$

Navedenim mjerama i kroz mrežu predstavnika NDH pri njemačkim zapovjedništvima trebalo je osigurati skladnu suradnju između NDH i njemačke vojske. No, niz izvora iz 1943. i 1944. godine pokazuju da je navedeno nerijetko bilo teško ostvariti.

Već krajem juna 1943. Ured ministra Lorkovića je od tijela državnih vlasti zatražio da dostave točne podatke kada je riječ o žalbama na postupke njemačke vojske, budući da će se samo na temelju njih moći uspješno intervenirati na takve slučajeve. ${ }^{26}$ Unatoč ovome, isti se Ured početkom avgusta iste godine ponovno obratio nadležnim vlastima. Objašnjeno je da tom uredu svakoga dana stižu dopisi različitih vlasti NDH sa žalbama na postupke njemačke vojske. Problem se i dalje nalazio u tome što žalbe nisu bile potkrijepljene konkretnim podacima. Zato je Ured ministra Lorkovića ponovno zatražio da nadležna ministarstva podređenim uredima narede da u svojim izvještajima navedu točan datum i mjesto određenog incidenta, sudionike i svjedoke događaja, odnosno imena njemačkih vojnika i nazive njemačkih jedinica. ${ }^{27}$

Nedugo nakon što je krajem 1943. poslove povezane s njemačkom vojskom preuzeo Ured pomoćnika ministra unutarnjih poslova, na čelu s ministrom Vrančićem, i taj je ured izdao dvije okružnice. U prvoj su upravne vlasti upućene da u slučajevima kada su njemački vojnici činili nasilja ili

\footnotetext{
${ }^{25}$ HR-HDA-1549, Zbirka zapisa upravnih i vojnih vlasti NDH i Narodnooslobodilačkog pokreta, III-13/1161-1162, NDH, Župska redarstvena oblast Nova Gradiška, Taj. Broj: 22/1945.

${ }^{26}$ HR-HDA-254, Velika župa Posavje, Taj. Broj: 2039/1943.

${ }^{27}$ HR-HDA-223, U. M. V. T. Broj: 224/1943.
} 
pljačke nad stanovništvom takve incidente trebaju rješavati vlasti NDH na lokalnoj razini. Tek u slučajevima da takva intervencija ne bude uspješna, trebalo se obratiti Uredu pomoćnika ministra unutarnjih poslova. ${ }^{28}$

U drugoj okružnici Ureda pomoćnika unutarnjih poslova upozoreno je da je važno da lokalne vlasti održavaju bliske kontakte s njemačkim zapovjedništvima, budući da će se na taj način spriječiti eventualni incidenti i nesuglasice. I u toj je okružnici naglašena važnost dostavljanja preciznih podataka kada je riječ o incidentima povezanim s njemačkom vojskom:

"Kod njemačkih častnika i vojnika ili drugih pripadnika njemačkih postrojbi treba u takvom slučaju navesti jedinicu, kojoj dotični pripadaju, naročito da li se radi o Wehrmachtu (njemačka vojska) ili SS-odredi, ili njemačkom redarstvu, ili njemačkom oružničtvu (Feldgendarmerie), a kad to nije moguće, navesti drugu koju oznaku (na pr. broj samovoza ili podvoza i sl.) iz koje se može saznati njihova pripadnost". ${ }^{29}$

Osim što je informacije o odnosima s Nijemcima trebalo dostavljati Uredu pomoćnika ministra unutarnjih poslova, o njima su mjesne vlasti trebale obavijestiti i opunomoćenike Vlade NDH pri njemačkim divizijama i višim zapovjedništvima, kako bi i oni intervenirali na rješavanju tih sporova. ${ }^{30}$

Do sredine 1944. Zapovjedništvo njemačke 2. oklopne armije očito je bilo sve manje spremno tolerirati neprestane žalbe NDH na držanje pripadnika te armije. Zato se to zapovjedništvo požalilo njemačkom opunomoćenom generalu u Zagrebu, Glaise von Horstenauu, zbog čestih pretjerivanja vlasti NDH u žalbama na postupke njemačke vojske. Nakon toga, Zagreb je upozorio podređene vlasti da ne treba isticati da se kod savezničke njemačke vojske stvara neraspoloženje ako je izložena neutemeljenim optužbama. Zato je još jednom ponovljeno da sve žalbe na njemačku vojsku moraju biti utemeljene. U suprotnom, a takvih je slučajeva bilo, neutemeljene optužbe

\footnotetext{
${ }^{28}$ HR-HDA-223, U. P. M. Taj. Broj: 566/1943.

${ }^{29}$ HR-HDA-223, U. P. M. Taj. Broj: 587/1943.

${ }^{30}$ Isto.
} 
na račun Nijemaca dovode vlasti NDH u nepovoljan položaj i štete savezničkim odnosima s Njemačkom. ${ }^{31}$

Sve navedeno ukazuje da su u odnosima između njemačke vojske i vlasti $\mathrm{NDH}$ bili prisutni različiti problemi. Stanje je dodatno pogoršala činjenica što je u jesen 1943. u NDH stigla i njemačka 1. kozačka divizija, koja se posebno isticala različitima oblicima nasilja i nediscipline. ${ }^{32}$ Navest ću samo neke primjere postupaka njemačke vojske koji su izazivali nezadovoljstvo vlasti NDH.

Kotarska ispostava u Bosanskoj Kostajnici se tijekom marta 1944. žalila na jedinicu iz sastava 1. kozačke divizije koja je u tom mjestu uvela policijski sat i zabranila kretanje noću. Ovime je zabranjeno i kretanje hrvatskih oružnika, općinskih redara i svih državnih službenika. Zahtjeve kotarske ispostave da se funkcionerima NDH omogući djelovanje tijekom noći, zapovjednik kozačke jedinice je odbio. Zato je zatražena intervencija Zagreba, kao i opunomoćenika NDH pri Zapovjedništvu 1. kozačke divizije, kako bi navedena njemačka zabrana bila povučena. ${ }^{33}$

$\mathrm{U}$ istom razdoblju, sredinom marta 1944, na držanje pripadnika njemačke 1. brdske divizije žalila se i Kotarska oblast u Bosanskom Novom:

"Prolazeća vojska I. brdska divizija, koja se je nekoliko dana povlačila prema Priedoru, zatim neka jedinica prema Kostajnici predstavljale su za grad i okolinu kuda su prolazili pravu najezdu skakavaca, koji su uništavali oko sebe sve do čega su došli. Narod je zaprepašten i na grubom postupku prema njima. Vojnici su se gurali u stanove ne vodeći računa o ženama i djeci, a poznato je da [je] pitanje povrede kućnog mira i odkrivanje žena veoma osjetljivo pitanje kod muslimana. Ljudi su ostali bez stočne hrane a mnogi i bez ljudske jer im je sve odnešeno" ${ }^{34}$

\footnotetext{
${ }^{31}$ HR-HDA-223, U. P. M. Taj. Broj: 2749/1944.

${ }^{32}$ Opširnije o toj diviziji vidi: Nikica Barić, "Njemačka 1. kozačka divizija u Slavoniji tijekom Drugoga svjetskog rata", u: Scrinia Slavonica, Godišnjak Podružnice za povijest Slavonije, Srijema $i$ Baranje Hrvatskog instituta za povijest, Vol. 18, Slavonski Brod: Hrvatski institut za povijest Podružnica za povijest Slavonije, Srijema i Baranje, 2018, 373-403.

${ }^{33}$ HR-HDA-223, U. P. M. Taj. Broj: 1278/1944.

${ }^{34}$ HR-DAKA-348, NDH, Velika župa Gora, Taj. Broj: 429/1944.
} 
I dok je njemačka 1. brdska divizija bila na prolazu kroz to područje, na njemu je bila smještena njemačka 373. "legionarska” pješačka divizija. Ona je iskazala spremnost da se evidentiraju i nadoknade štete pričinjene stanovnicima Bosanskog Novog, obećavši da će biti isplaćeno dva milijuna kuna odštete. No, do trenutka kada je uputila svoj izvještaj o postupcima njemačke vojske, Kotarska oblast Bosanski Novi morala je zaključiti da taj novac još uvijek nije bio isplaćen. ${ }^{35}$ Nedugo kasnije predstavnici NDH upozorili su da su se tijekom februara i marta 1944. na području sjeverozapadne Bosne, a zatim na području oko Petrinje, pojavile jedinice njemačke 1. brdske divizije. Bila je riječ o velikoj jedinici, koja je u svome pokretu stanovništvu pričinila znatne štete. Nakon intervencije predstavnika NDH zapovjednik te divizije, general Walter Stettner, pokazao je spremnost da se isplate opravdani odštetni zahtjevi. Budući da je ta divizija više mjeseci djelovala na teritoriji $\mathrm{NDH}$, ocijenjeno je da bi bilo potrebno pri njoj odrediti predstavnika $\mathrm{NDH}$, kakvi su djelovali kod drugih njemačkih divizija. ${ }^{36}$

U pojedinim slučajevima dolazilo je i do incidenata između pripadnika snaga NDH i njemačkih vojnika. Nakon što su u januaru 1944. ustaše u blizini Zagreba zabranili kretanje pripadnicima 1. kozačke divizije, štoviše ustaše su ove željeli razoružati i uhapsiti, moralo je intervenirati Ministarstvo oružanih snaga NDH. Ono je u svojoj okružnici, koja je sastavljena u dogovoru s njemačkim opunomoćenim generalom u Zagrebu, objasnilo da snage NDH nemaju pravo razoružati ili spriječiti u djelovanju njemačke vojnike koji rade po zapovijedi viših zapovjednika. Ako njemačka vojska na temelju dogovora s NDH provodi rekvizicije hrane, snage NDH to ne smiju sprečavati. Ako Nijemci po selima otimaju, pljačkaju i vrše nasilje nad hrvatskim stanovništvom, o tome je trebalo obavijestiti najbliže njemačko zapovjedništvo. U takvim slučajevima domobrani i ustaše mogli su pojedine njemačke vojnike uhapsiti i razoružati i zatim predati, s oduzetim oružjem, njemačkom zapovjedništvu. Pri svemu ovome trebalo je izbje-

${ }^{35}$ Isto.

${ }^{36}$ HR-HDA-223, U. P. M. Taj. Broj:1528/1944. 
gavati eventualnu eskalaciju sukoba, odnosno i otvoreni oružani sukob s njemačkim vojnicima. ${ }^{37}$

\section{Stradanje civilnog stanovništva}

Razumljivo, opisani problemi u odnosima vlasti NDH i njemačke vojske imali su manje teške posljedice od stradavanja stanovništva od strane njemačke vojske. Navest ću samo neke primjere takvog stradanja stanovništva u Bosni i Hercegovini, budući da i recentna literatura ukazuje da su takvi slučajevi bili puno brojniji i da je pri tome bilo mnogo civilnih žrtava. ${ }^{38}$

Jedinice SS-divizije "Prinz Eugen" su početkom 1943, u sklopu operacije "Weiss", na području Bosanskog Petrovca naišli na skupinu od oko 60 izbjeglica, žena, djece i staraca. Oni su SS-ovcima izjavili da u blizini nema partizana, a SS-ovci su im izdali potvrde da se mogu vratiti svojim kućama. Ubrzo zatim ista njemačka jedinica naišla je na partizansku zasjedu, nakon čega su SS-ovci strijeljali spomenutu skupinu izbjeglica. U kasnijem izvještaju te divizije navedeno je - možda kako bi se opravdale spomenute likvidacije - da je kod jednoga strijeljanog izbjeglice pronađena isprava koja je pokazivala da je bila riječ o suradniku partizana. ${ }^{39}$

Muslimanski seljaci su 7. jula 1943. u blizini Goražda pronašli tijelo jednog ubijenog njemačkog vojnika. Seljaci su ovo prijavili njemačkom zapovjedništvu u Goraždu i također su pomogli da leš njemačkog vojnika bude prenesen u to mjesto. No, idućega dana, 8. jula, na područje gdje je pronađen mrtav Nijemac, stigla je njemačka vojska iz Goražda. Ona je bez ispitivanja prikupila 31 Muslimana, među kojima je bilo i žena i djece, te su ih strijeljali. ${ }^{40}$

\footnotetext{
${ }^{37}$ HR-HDA-1197, Oružničko krilno zapovjedništvo Dubrovnik, Taj. Broj: 196/1944.

${ }^{38}$ Vidi: R. Hurem, Bosna i Hercegovina u Drugom svjetskom ratu 1941-1945, 311-317.

${ }^{39}$ Zbornik dokumenata i podataka o Narodnooslobodilačkom ratu jugoslovenskih naroda, Tom IV, Knjiga 11, Borbe u Bosni i Hercegovini 1943 god, Beograd: Vojnoizdavački zavod "Vojno delo", 1955, dok. br. 293.

${ }^{40}$ Zbornik dokumenata i podataka o Narodnooslobodilačkom ratu jugoslovenskih naroda, Tom IV, Knjiga 15, Borbe u Bosni i Hercegovini 1943 god, Beograd: Vojnoistorijski institut, 1956, dok. br. 244.
} 
Partizani su 10. jula 1943. ušli u selo Košuticu u blizini Sokolca i ubrzo se sukobili s njemačkom vojskom, pri čemu je poginuo jedan njemački vojnik. Jedinice SS-divizije "Prinz Eugen" su 12. jula natjerale partizane na povlačenje iz Košutica. SS-ovci su zatim sakupili seljake u džamiji, nakon čega su ih strijeljali. Ukupno je ubijeno 69 ljudi, među kojima je bilo i žena i djece. Desetak seljaka uspjelo se sakriti i spasiti živote, a pronađeno je četvero ranjene djece koja su upućena u bolnicu u Sarajevo. Vojne vlasti $\mathrm{NDH}$ uputile su povjerenstvo u Košuticu, koje je izvršilo uviđaj o ovom događaju. ${ }^{41}$

Nedugo kasnije, sredinom jula 1943, Kotarska oblast u Nevesinju izvijestila je da je njemačka vojska nedugo prije pobila oko 300 seljaka u nekoliko sela na tom području, dok su sama sela opljačkana i spaljena. Bila je riječ o selima: Donji Drežanj, Humčani, Krekovi, Ljeskov Dub, Udrežnje. Razlog za ovo bio je što su se u tim selima skrivali partizani, kao i pogibija jednog njemačkog vojnika kojega su, navodno, ubili seljaci iz jednog od tih sela. U vezi s ovim događajima Kotarska oblast u Nevesinju je izvijestila:

"Povodom ovih paljenja pravoslavni živalj u ovome kotaru je u velikom strahu i po selima ni jedan muškarac ne noćiva kod kuće nego u šumi, jer se boje paljenja i slično". ${ }^{42}$

Njemačka vojska je 22. oktobra 1943. vodila akcije protiv partizana istočno od Sarajeva. Nijemci su tom prilikom spalili sela Hotičina i Stajna i pobili dio stanovnika tih sela, među kojima je bilo i Muslimana i Srba. Preostalo stanovništvo ovih sela Nijemci su doveli u Pale. Tamo su Muslimani ubrzo pušteni kućama, dok je 18 Srba upućeno u Sarajevo. Nijemci nisu dopustili vlastima NDH da ustanove što se dogodilo u navedenim selima, odnosno koliko je ljudi pobijeno, pod obrazloženjem da na tom području i dalje traju borbe. ${ }^{43}$

${ }^{41}$ Historijski muzej Bosne i Hercegovine, Sarajevo, Zbirka Ustaške nadzorne službe, Broj dokumenta: 1948, NDH, Vrhovno oružničko zapovjedničtvo, Odjel za javnu sigurnost, Taj. Broj: 2147/1943. ${ }^{42}$ Zbornik dokumenata i podataka o NOR-u jugoslovenskih naroda, Tom IV, Knjiga 15, dok. br. 251.

${ }^{43}$ Zbornik dokumenata i podataka o Narodnooslobodilačkom ratu jugoslovenskih naroda, Tom IV, Knjiga 18, Borbe u Bosni i Hercegovini 1943 god, Beograd: Vojnoistorijski institut, 1958, dok. br. 204. 
Očito su zbog ovakvih slučajeva stanovnici određenih mjesta, kada bi saznali da mu se približava njemačka vojska ili snage NDH, napuštalo domove, strahujući da bi moglo stradati. Ministarstvo unutarnjih poslova NDH je u oktobru 1943. o takvim slučajevima obavijestilo vlasti u cijeloj državi. Navedeno je da stanovništvo bježi iz svojih domova zbog neprijateljske propagande koja među narodom širi "klevete" protiv hrvatskih i njemačkih oružanih snaga. Zato je određeno da se u cijeloj NDH istaknu oglasi u kojima je trebalo navesti da stanovništvo nema razloga za strah i ono snage NDH, odnosno njemačku vojsku, treba dočekati s "ljubavlju i povjerenjem". Stanovništvo ne smije nasjedati neprijateljskoj propagandi i bježati iz svojih domova. Svatko onaj tko bude bježao smatrat će se odmetnikom, te će u skladu s time snositi posljedice. Upozoreno je da će se u kućama koje su stanovnici napustili smjestiti vojska, koja će za vlastite potrebe iskoristiti napuštenu hranu i stoku. Zato je stanovništvo pozvano da ostane kod svojih kuća i bavi se svojim redovitim poslovima, a snage NDH i njemačka vojska u tome će ga štititi i osiguravati od odmetnika. ${ }^{44}$

\section{Odmazde}

Režim NDH je svojim zakonskim i drugim odredbama uspostavio sistem strogoga kažnjavanja pojedinaca i skupina koje je smatrao nepodobnim ili neprijateljskim. Uz rasno zakonodavstvo, usmjereno protiv Roma i Židova, kao i niz odredbi usmjerenih protiv Srba, bile su tu i mjere koje su vlastima NDH omogućavale oštro kažnjavanje, od smrtnih kazni do deportacija u koncentracijske logore. Ovo je uključivalo i kolektivno kažnjavanje, odnosno za određena djela nisu kažnjavani izravni počinitelji, koji nisu bili dostupni, nego su, u obliku odmazdi, kažnjavani drugi pojedinci (taoci), koji su po određenim mjerilima smatrani (su)odgovornima za navedena djela. ${ }^{45}$

\footnotetext{
${ }^{44}$ HR-HDA-254, Taj. Broj: 2887/1943.

${ }^{45}$ Leopold Kobsa, “O organizaciji ustaškog aparata vlasti za provođenje terora u tzv. NDH”, u: Zagreb u NOB-i i socijalističkoj revoluciji, Materijali sa znanstvenog skupa održanog u Zagrebu 29. i 30. lipnja 1970. u povodu 25. godišnjice oslobođenja grada Zagreba, Zagreb: Institut za historiju radničkog
} 
Mjere odmazde primjenjivala je i njemačka vojska. Tijekom 1941. godine, kada su Nijemci gušili ustanak u Srbiji, oni su za odmazdu strijeljali na tisuće civila. No, general Glaise von Horstenau se sredinom oktobra 1941. obratio generalu Baderu, njemačkom zapovjedniku u Srbiji. Budući da su u tom razdoblju i njemačke snage u NDH bile pod zapovjedništvom Badera, Glaise von Horstenau ga je upozorio da one ne mogu provoditi odmazde na način na koji se to činilo u Srbiji. Zapravo su njemački predstavnici u Zagrebu dogovorili s vlastima NDH da mjere odmazde provode njezine vlasti, koje su nedugo prije donijele Zakonsku odredbu o postupku kod komunističkih napadaja, kad se počinitelj ne pronađe, kojom je predviđeno i provođenje odmazdi nad taocima. Zato je Glaise von Horstenau zatražio od Badera da njemačke jedinice u NDH o ovome vode obzira i da u svome djelovanju po ovom pitanju surađuju s predstavnicima NDH. ${ }^{46}$

Kao što sam prethodno naveo, general Lüters je u svojoj zapovijedi od 12. januara 1943. među ostalim odredio da uhapšene sumnjive osobe treba iskoristiti kao taoce za vršenje mjera odmazde. Otprilike mjesec dana kasnije, 13. februara 1943, na području Viteza izvršen je napad na jedan vlak, u kojem je poginulo ili ranjeno više od 30 domobrana. Prema informacijama vlasti NDH, napad na vlak izvršio je Zenički četnički odred. Nakon ovoga njemačka vojska je za odmazdu strijeljala 9 Srba iz sela Tolovići, ali su također uhapsili i 25 Hrvata i Muslimana s područja općine Vitez. ${ }^{47}$

U navedenom slučaju Nijemci su za odmazdu strijeljali Srbe. No, upravo general Lüters, zapovjednik njemačkih trupa u Hrvatskoj, nije smatrao da kao taoce za odmazdu treba uzimati isključivo Srbe. On se u dopisu kojega je početkom juna 1943. uputio generalu Glaise von Horstenauu žalio na

pokreta Hrvatske, 1971.; Nikolina Srpak, "Kazneno pravo u doba Nezavisne Države Hrvatske (1941.-1945.)", u: Hrvatski ljetopis za kazneno pravo i praksu, Zagreb: Hrvatsko udruženje za kaznene znanosti i praksu, Vol. 13, br. 2, 2006, 1117-1144.

${ }^{46}$ Zbornik dokumenata i podataka o Narodnooslobodilačkom ratu naroda Jugoslavije, Tom XII, Knjiga 1, Dokumenti Nemačkog Rajha 1941, Beograd: Vojnoistorijski institut, 1973, dok. br. 198.

${ }^{47}$ Zbornik dokumenata i podataka o Narodnooslobodilačkom ratu jugoslovenskih naroda, Tom IV, Knjiga 10, Borbe u Bosni i Hercegovini 1943 god, Beograd: Vojnoizdavački zavod "Vojno delo", 1954, dok. br. 339. 
vlasti NDH, odnosno na ustaše, smatrajući da njihovi postupci onemogućavaju smirivanje stanja. Naveo je primjer njemu dodijeljenoga glavara građanske uprave Aleksandra Benaka, koji je zahtijevao da se zbog napada na vlakove uzmu taoci, ali isključivo Srbi, inzistirajući da hrvatsko (katoličko, muslimansko) stanovništvo nema nikakve veze s tim napadima. ${ }^{48}$ Očito, Lüters je, za razliku od Benaka, smatrao da teret odmazdi trebaju "ravnopravno" snositi svi dijelovi stanovništva.

General Lüters je krajem avgusta 1943. izdao smjernice o provođenju odmazdi nakon napada na prometnice. On je ovlastio divizije pod svojim zapovjedništvom da, u suradnji s predstavnicima njemačkih sigurnosnopolicijskih službi, odrede tko će biti uzet za taoce. Pri tome je objasnio da taoce treba uzeti "bez obzira na narodnu pripadnost". 49

Za taoce je trebalo uzeti članove obitelji ustanika, ustanicima naklonjene osobe, kao i sumnjive osobe. Njemačka Tajna vojna policija, odnosno Služba sigurnosti trebala je uhapsiti ove osobe, a hapšenja su mogle izvršiti i vlasti $\mathrm{NDH}$. Uhapšene taoce trebalo je uputiti u njemačke logore u Prijedoru ili Zenici, a predviđeno je i osnivanje logora za taoce u drugim dijelovima $\mathrm{NDH} .{ }^{50}$

Hapšenje taoca trebalo je oglasiti plakatima i trebalo je najaviti provođenje odmazde, a također je iz njemačkih aviona trebalo bacati letke nad područjima na kojima se dogodio napad, odnosno iz kojih potječu taoci, kao i na područjima gdje djeluju partizani. U tim je letcima trebalo navesti osnovne osobne podatke o taocima i uz to zaprijetiti da će oni biti strijeljani kao odmazda za buduće napade. ${ }^{51}$

Nakon provođenja odmazde, odnosno strijeljanja taoca, i to je trebalo objaviti na prethodno opisan način, uz navođenje osobnih podataka o likvidiranim taocima i zbog kojih su sabotaža strijeljani. Zapovjednik

${ }^{48}$ HR-HDA-1450, rola D-88, snimke 1188-1189, Deutscher Bevollm. General in Kroatien, Nr. 01115/43 g. Kds, Abt. II a.

${ }^{49}$ Građa za povijest Narodnooslobodilačke borbe i socijalističke revolucije u sjeverozapadnoj Hrvatskoj 1941 -1945, Knjiga VI (rujan - listopad 1943), Zagreb 1987, dok. br. 4.

${ }^{50}$ Isto.

${ }^{51}$ Isto. 
nadležne njemačke divizije trebao je odlučiti hoće li se likvidacije taoca provesti na mjestu napada zbog kojeg je određena odmazda, ili u logoru u kojem su taoci zatočeni. Pri tome je izvršenje egzekucije taoca, ako je to moguće, trebalo prepustiti policiji NDH. Načelno je odmazde trebalo izvršiti za svaki budući slučaj napada ili sabotaža. ${ }^{52}$

Upravo u razdoblju u kojem je general Lüters izdao ove smjernice za provođenje odmazdi, došlo je do promjene u sistemu zapovijedanja njemačke vojske na teritoriji NDH. Zapovjedništvo nad tim jedinicama preuzeo je general Lothar Rendulic, zapovjednik 2. oklopne armije. Rendulic je 15. rujna 1943. odredio da se za svakog njemačkog vojnika ubijenog u partizanskim prepadima strijelja ili objesi 50 taoca, a za svakog njemačkog vojnika ranjenog u takvim prepadima trebalo je strijeljati ili objesiti 25 taoca. ${ }^{53}$

Iako su i same vlasti NDH koristile sistem odmazdi, očito su omjer talaca koji je odredio Rendulic smatrale pretjeranim. Tako je u jednom dopisu Glavnog stožera Ministarstva oružanih snaga NDH navedeno da njemačka vojska ne može pitanje odmazdi u NDH rješavati na način na koji to čini u neprijateljskim, odnosno okupiranim zemlja. Provođenje razine odmazde koju predlaže njemačka 2. oklopna armija izazvalo bi "metež i pobunu" stanovništva. Odnosno, kako je objašnjeno, hrvatski je narod uvijek imao poštovanje prema Nijemcima, ali će se ono pretvoriti u ogorčenje ako oni budu provodili tako oštre odmazde. Pri tome ni u samom Glavnom stožeru nisu dovodili u pitanje potrebu provođenja odmazdi, ali je zaključeno da taoci mogu biti isključivo članovi obitelji partizana i osobe za koje se pouzdano utvrdi da su suradnici partizana, dok u cilju smirivanja stanja u državi treba odustati od uzimanja drugih taoca. ${ }^{54}$

\footnotetext{
${ }^{52}$ Isto.

${ }^{53}$ Europa unterm Hakenkreuz. Die Okkupationspolitik des deutschen Faschismus (1938-1945), Achtbändige Dokumentenedition, Band 6, Die Okkupationspolitik des deutschen Faschismus in Jugoslawien, Griechenland, Albanien, Italien und Ungarn (1941-1945), Berlin-Heidelberg: Hüthig Verlagsgemeinschaft, 1992, 256-257.

${ }^{54}$ HR-HDA-1450, rola D-2237, snimke 168-169, [NDH, Ministarstvo oružanih snaga, Glavni stožer, Izvještajni odjel, Taj. Broj:] 6541/1944.
} 
Predstavnici NDH intervenirali su kod Nijemaca kako omjer odmazdi koje je predlagao general Rendulic ne bi bio primijenjen i kako bi provođenje odmazdi ostalo u nadležnosti vlasti NDH. Zato su vlasti NDH 30. oktobra 1943. donijele i novu Zakonsku odredbu o zaštitnim mjerama zbog napadaja i čina sabotaže protiv javnog reda i sigurnosti, pri čemu se pod "zaštitnim mjerama" mislilo na mjere odmazde. Tom odredbom razrađeno je na koji način, nakon napada i sabotaža partizana, a kada su počinitelji nepoznati ili ih se ne može uhapsiti, treba provesti odmazde nad osobama za koje se utvrdi da su te napade “pomagale", ili za one za koje je utvrđeno da su "djelatni komunisti ili odmetnici”. U određenim slučajevima odmazdu je trebalo provesti i nad članovima obitelji onih koji su počinili napade. Pod "zaštitnim mjerama” podrazumijevalo se strijeljanje (ili vješanje) taoca, odnosno njihovo upućivanje u koncentracijski logor i oduzimanje imovine koja je prelazila u vlasništvo $\mathrm{NDH} .{ }^{55}$

Njemački opunomoćeni general Glaise von Horstenau je početkom marta 1944. obavijestio Ministarstvo unutarnjih poslova NDH da je njemački vrhovni zapovjednik na Balkanu izdao nove smjernice za provođenje odmazdi, u cilju suzbijanja "komunističke opasnosti”. Smjernice su opširno razrađivale kako provesti odmazde nakon napada na njemačke vojnike ili nakon sabotaža. Pri tome nije bio zadan omjer odmazde, odnosno njega je očito trebalo primijeniti ovisno o određenom slučaju. Također je opširno objašnjeno koje skupine stanovništva treba uzeti za taoce, a koje su osobe od toga isključene (državni službenici ili osobe poznate kao "neprijatelji komunizma”). Pri tome je, kada je riječ o NDH, njemačkoj vojsci kao "načelo" za provođenje odmazdi trebala biti spomenuta Zakonska odredba o zaštitnim mjerama od 30. oktobra 1943, na temelju koje je od vlasti NDH trebalo zahtijevati provođenje odmazdi. Pri tome su za čuvanje "hrvatskih probitaka” pri provođenju odmazdi bili nadležni opunomoćenici NDH imenovani pri njemačkim zapovjedništvima. ${ }^{56}$

\footnotetext{
${ }^{55}$ B. Krizman, Ustaše i Treći Reich, Prvi svezak, 181-182, 278-280. Za tekst navedene zakonske odredbe vidi: Nezavisna Država Hrvatska, Zakoni, zakonske odredbe, naredbe i t. d. proglašene od 23. listopada do 27. studenoga 1943, Knjiga XXXIX. (svezak 381.-390.), Uređuje: A. Mataić, Zagreb: Knjižara St. Kugli, 1943, 98-101.

${ }^{56}$ HR-HDA-1197, Taj. Broj: 554/1944.
} 
Kao što je vidljivo, vlasti NDH, iako su i same vlastitim zakonskim odredbama omogućile široki raspon kolektivnog kažnjavanja i odmazdi, težile su da provođenje odmazdi ne bude potpuno prepušteno njemačkoj vojsci, budući da su smatrale da bi u tom slučaju mogle stradati i one osobe koje su su smatrale vjernima NDH.

\section{Deportacije u Njemački Reich}

Postupno će represivne mjere njemačke vojske u NDH postati povezane s njemačkom težnjom da se $s$ tog područja što više ljudi odvede na (prisilni) rad u gospodarstvu Njemačkog Reicha. ${ }^{57}$

Neposredno pred početak operacije "Weiss", general Lüters je u svojoj zapovijedi za vođenje borbe na području NDH od 12. januara 1943. naveo da stalnim "pročešljavanjem zemlje" svi za oružje sposobni muškarci, što je moguće prije, trebaju biti u "velikoj mjeri” odvedeni iz zemlje. Zato je s područja koja su smatrana sumnjivima zbog djelatnosti partizana vojno sposobni muškarci, pri čemu su u obzir uzeti i maloljetnici od 15 godina i stariji, trebali biti odvedeni u posebne sabirne logore. ${ }^{58}$

Nedugo kasnije, u Zagrebu je 16. januara 1943. održan sastanak predstavnika njemačke vojske na kojem je dogovoreno kako tijekom operacije "Weiss" postupati sa zarobljenicima. Pri svakoj njemačkoj diviziji dio zarobljenika trebalo je zadržati za razmjenu zarobljenika s partizanima, a dio kao taoce za provođenje odmazdi. Ostale radno sposobne osobe za koje se smatralo da su sumnjive, odnosno nepouzdane, trebalo je preko logora u Osijeku uputiti na rad u Njemačku. Dokazano sumnjive radno sposobne zarobljenike, trebalo je preko logora u Zemunu uputiti na rad u Norvešku. Zarobljenike o kojima, u pogledu pouzdanosti, nije moguće donijeti konačan zaključak, trebalo je uputiti u logor u Sisak, gdje je nad njima trebalo provesti daljnju istragu. General Glaise von Horstenau

${ }^{57}$ Opširno o tome vidi: Sanela Hodžić, Christian Schölzel, Zwangsarbeit und der Unbhängige Staat Kroatien 1941 -1945, Berlin-Münster: Lit Verlag Dr. W. Hopf, 2013, 3-127.

${ }^{58}$ Zbornik dokumenata i podataka o NOR-u jugoslovenskih naroda, Tom IV, Knjiga 9, dok. br. 215. 
zadržao je pravo da se iz logora oslobode oni za koje interveniraju vlasti $\mathrm{NDH} .{ }^{59}$

Nedugo kasnije general Lüters je vlastima NDH dostavio smjernice o postupku sa zarobljenicima i izbjeglicama tijekom provođenja operacija protiv partizana. Svatko tko je zarobljen, a bio je naoružan, trebao je biti strijeljan. Ostali zarobljenici, odnosno osobe koje nisu zatečene s oružjem, ali su se nalazili na području gdje su vođene borbe, trebali su biti upućeni u njemačke zarobljeničke logore. ${ }^{60}$

Izbjeglice, odnosno one koji su pred Nijemcima napustili svoje domove, trebalo je razvrstati. Radno sposobne muške izbjeglice, stare između 16 i 50 godina, trebalo je svrstati zajedno sa zarobljenicima. Ostale izbjeglice, žene, djecu, starije muškarce i radno nesposobne trebalo je predati vlastima NDH. Kada je riječ o stanovništvu koje nije napuštalo domove, njega je trebala ispitati njemačka vojska ili vlasti NDH. Sumnjive među ovima trebalo je izvesti pred prijeki sud, ili ih je trebalo razvrstati na isti način kao i izbjeglice. ${ }^{61}$

$S$ početkom operacije "Weiss", odnosno udarom osovinskih snaga na područje "Bihaćke republike", s partizanima se u zbjegovima počelo povlačiti i više tisuća stanovnika s tih područja.$^{62} \mathrm{No}$, ne raspolažem podatcima koliko su zarobljenika i civila Nijemci, u skladu sa svojim planovima, deportirali na rad u Njemačku ili Norvešku.

Kada je riječ o vlastima NDH, njima je odgovaralo da Nijemci tijekom provođenja operacije "Weiss" deportiraju u Njemačku one dijelove stanovništva koje su i te vlasti smatrale nelojalnima, ali ne i one koje su smatrale

${ }^{59}$ Zbornik dokumenata i podataka o Narodnooslobodilačkom ratu naroda Jugoslavije, Tom XII, Knjiga 3, Dokumenti Nemačkog Rajha 1943, Beograd: Vojnoistorijski institut, 1978, dok. br. 11.

${ }^{60}$ HR-HDA-1198, Taj. Broj: 556/1943.; Antun Miletić, Koncentracioni logor Jasenovac 1941-1945, Dokumenta, Knjiga II, Beograd-Jasenovac: Narodna knjiga, Spomen-područje Jasenovac, 1986, dok. br. 244.

${ }^{61}$ Isto.

${ }^{62}$ Vlado Stojanović, “Zbjegovi naroda na područjima zahvaćenim operacijama 'Weiss' i 'Schwarz' 1943. godine", u: Zbornik radova naučnog skupa "Neretva - Sutjeska 1943" održanog od 27. juna do 2. jula 1968. god. u Sarajevu, Odgovorni urednik: Branko Borojević, Beograd: Vojnoistorijski institut, 1969, 286-292. 
lojalnima. Tako je državni tajnik Vjekoslav Vrančić 25. januara 1943. uputio telegram ministru Ivici Frkoviću, tada predstavniku NDH pri njemačkoj vojsci, u kojem mu je dao sljedeće upute:

"Ne posredujte za oslobođenje njemačkih zarobljenika ako to nisu posve pouzdani katolici i muslimani. Posredujte iznimno i pojedinačno samo za one prelaznike [Srbe koji su prethodno prešli na katoličku ili neku drugu priznatu vjeru] ili pravoslavne, koji su se istakli svojim radom na smirivanju svoga kraja, te čija prisutnost jamči daljnji uspjeh smirivanja. Sve što je i malo nepouzdano odlazi na rad u Njemačku. Umirite izravno ili preko područnih oblasti zarobljenike i njihove obitelji s time, da idu na rad". ${ }^{63}$

U pojedinim slučajevima vlasti NDH težile su osloboditi osobe deportirane u Njemačku. Tako je Džafer Kulenović, potpredsjednik Vlade NDH, tijekom jula 1943. zatražio od Ureda ministra Lorkovića da intervenira kod Nijemaca za oslobađanje određenog broja Muslimana iz Bihaća, odnosno Kulen Vakufa, koje su Nijemci zarobili i preko logora u Zemunu uputili na rad u Njemačku. U vezi s ovim osobama navedeno je da su ih partizani prisilno poveli sa sobom, kada su se u januaru 1943. povlačili pred njemačkim napredovanjem. Oni su uspjeli pobjeći partizanima i predali su se njemačkoj vojsci, da bi zatim bili odvedeni na rad u Njemačku. ${ }^{64}$ Nemam podataka kako je riješen ovaj slučaj.

U decembru 1943. Ministarstvo unutarnjih poslova NDH raspolagalo je informacijama da se u njemački logor u Zemunu privode brojne osobe, među kojima ima i "Hrvata katolika i muslimana, a u većini slučajeva radi se o ženama”. Budući da su Nijemci u taj logor privodili državljane NDH bez sudjelovanja njezinih vlasti, i budući da nije bilo poznato što se dalje s tim osobama događa, ocijenjeno je da bi Ured pomoćnika ministra unutarnjih poslova trebao intervenirati kod Nijemaca, kako bi neke osobe zatočene u logoru u Zemunu bile oslobođene. ${ }^{65}$

\footnotetext{
${ }^{63}$ HR-HDA-1549, I-79/9, U.N.S. Zagreb, Službena brzojavka, Broj 711, 25/I. [1943], Priepis: Šetinc. ${ }^{64}$ HR-HDA-212, Predsjedništvo vlade NDH, Ured ministra Lorkovića, Broj: 259/1943.

${ }^{65}$ HR-HDA-223, U. P. M. Taj. Broj: 2357/1944.
} 
Navedeno je ukazivalo da Nijemci interniraju i deportiraju državljane $\mathrm{NDH}$ bez dogovora s njezinim vlastima. Zabrinutost u vezi s ovime pokazuje i okružnica Predsjedništva vlade NDH iz januara 1944. u kojoj je navedeno da su njemačke jedinice u nekoliko slučajeva otpremile hrvatske državljane na rad u Njemačku. Ako bi se takvi slučajevi ponovili, o njima je odmah trebalo obavijestiti ministra oružanih snaga NDH, kako bi on mogao intervenirati kod visokih predstavnika njemačke vojske da se s takvim deportacijama prekine. ${ }^{66}$

Nasuprot ovome stajalo je stanje na terenu, gdje su Nijemci nastavili deportirati civile u Njemačku. Tako je, primjerice, Kotarska oblast u Bosanskom Novom sredinom marta 1944. izvijestila da njemačka vojska i maloljetnike, dječake, odnosno mladiće stare od 14 do 17 godina, upućuje na rad u Njemačku, budući da bi i oni mogli poslužiti za radove u poljoprivredi. ${ }^{67}$

Krajem maja 1944. ministar oružanih snaga, ustaški pukovnik Ante Vokić, u jednom je dopisu naveo da njemačke jedinice tijekom svojih operacija "često pokupe" radno sposobno stanovništvo koje otpremaju na rad u Njemačku. Nijemci na takav način sve više odvode i maloljetnike, pa takvo stanje predstavlja "ozbiljnu opasnost" za stanovništvo NDH i za autoritet njezinih vlasti. ${ }^{68}$

Kao što je vidljivo, vlasti NDH s jedne su strane bile zadovoljne rješenjem da se na rad u Njemačku upute oni koje su one smatrale nepodobnima. No, sa sve većim ovlastima koje je zadobila njemačka vojska, ona je počela deportirati i ono stanovništvo, koje su vlasti NDH smatrale lojalnim, čime su te vlasti gubile povjerenje tog istog stanovništva.

\section{Partizani kao zarobljenici i partizanski prebjezi}

Kao što je u ovom prilogu opisano, Nijemci su partizane smatrali "banditima" i naredbe njemačkih zapovjedništava bile su da se partizane (i njihove suradnike) ne zarobljava, nego da ih se na licu mjesta strijelja. No, u

\footnotetext{
${ }^{66}$ HR-HDA-216, Ured ministra, Taj. Broj: 368/1944.

${ }^{67}$ HR-DAKA-348, NDH, Velika župa Gora, Taj. Broj: 429/1944.

${ }^{68}$ HR-HDA-1549, III-45/16-18, NDH, Ministarstvo unutarnjih poslova, Glavno ravnateljstvo za javni red i sigurnost, Taj. Broj: 2605/1944.
} 
ovom postupku doći će do promjena. Tako su tijekom jula 1943. njemačke jedinica u NDH dobile nove upute za postupak s partizanima. Hitler je odlučio da "bandite" više ne treba strijeljati, nego je s njima trebalo postupati kao sa zarobljenicima, kako bi ih se upotrijebilo kao radnu snagu. Sa strijeljanjem partizana trebalo je prekinuti i kako bi im se dao poticaj da se predaju. Naime, budući da su partizani znali da ih u slučaju zarobljavanja očekuje strijeljanje, to ih je odvraćalo od predaje. Ako bi se prekinulo sa strijeljanjem zarobljenih partizana, moglo se očekivati da će se više njih predati. U skladu s navedenim, nova smjernica za njemačke jedinice bila je da se zarobljene partizane od 16 do 55 godina starosti započne privoditi $u$ sabirne stanice za zarobljenike. ${ }^{69}$

Vrhovno zapovjedništvo Njemačkih oružanih snaga je sredinom avgusta 1943. dodatno pojasnilo postupak sa zarobljenim partizanima. Tako je određeno da se neće postupati kao sa zarobljenicima s onim partizanima koji su zarobljeni u uniformi njemačke ili neke njoj savezničke vojske, nego je takve nakon ispitivanja trebalo strijeljati. Također je određeno da nakon posebno "podmuklih" postupaka partizana nadležni zapovjednik njemačke divizije može odrediti da se partizane ne zarobljava, nego da budu strijeljani, a isto se moglo postupiti i s civilima. Osim toga ponovno je spomenuta i kategorija "prebjega", pod čime se mislilo na partizane koji se Nijemcima predaju dobrovoljno, bez borbe. ${ }^{70}$

U decembru 1943. Nijemci su odlučili provesti dodatne mjere kako bi se partizane potaknulo na dobrovoljnu predaju. U tom je razdoblju general Glaise von Horstenau obavijestio vlasti NDH da su viša njemačka zapovjedništva odredila da treba provesti propagandne mjere, kako bi se pripadnike "komunističkih bandi" navelo na predaju. Ako se u ovome želi postići uspjeh, trebalo je voditi računa o korektnom postupku s onima koji odluče napustiti redove partizana. Njima je trebalo jamčiti život, osigurati im mogućnost zaposlenja, odnosno omogućiti im da se vrate svojim domovima. Zato se više nije smjelo događati da se strijeljaju partizani koji

${ }^{69}$ Zbornik dokumenata i podataka o NOR-u jugoslovenskih naroda, Tom IV, Knjiga 15, dok. br. 232. ${ }^{70}$ Zbornik dokumenata i podataka o NOR-u jugoslovenskih naroda, Tom IV, Knjiga 18, dok. br. 184. 
su se predali. Vlasti NDH su partizane koji im se predaju morale predati Nijemcima. Pri tome je objašnjeno da se kao povratnike iz partizana treba smatrati osobe koje se predaju dobrovoljno, izvan borbe. Nasuprot tome, partizane koji su zarobljeni tijekom vođenja borbi trebali su biti upućeni u njemačke zarobljeničke logore. ${ }^{71}$

Kada je riječ o spomenutim "propagandnim mjerama” koje je trebalo upotrijebiti kako bi se partizane potaknulo na predaju, pri tome se, primjerice, mislilo na različite letke koje su bacali njemački avioni. U njima su partizani upozoravani na besmislenost svoje borbe i pozivani na predaju. ${ }^{72}$

Na području njemačkog XV. brdskog armijskog korpusa (koji je formiran iz Zapovjedništva njemačkih trupa u Hrvatskoj) tijekom decembra 1943. evidentirano je 914 prebjega, a tijekom januara 1944. ukupno 576 prebjega. Do početka februara 1944. dio tih prebjega prijavio se za odlazak na rad u Njemačku, neki su se javili da služe kao pripadnici protuavionske obrane u Njemačkoj, ili kao pripadnici pomoćnih jedinica njemačke vojske u NDH. Neki su predani vlastima NDH, kako bi bili uvršteni u domobranske ili ustaške jedinice, a dio prebjega pušten je kućama. ${ }^{73}$

U vezi s ovime zanimljiva je jedna bilješka izrađena u Ministarstvu unutarnjih poslova NDH tijekom 1943. godine. U njoj je naveden niz slučajeva Muslimana koje su Nijemci uhapsili, internirali u svoje logore ili uzeli za taoce. Nakon toga Ured ministra Lorkovića primao je molbe u kojima se tražila intervencija za te ljude, odnosno njihovo oslobađanje. U bilješci je zaključeno da Nijemci sa svoje strane zahtijevaju da se iz logora NDH pusti određeni broj Muslimana, kako bi oni bili uvršteni u hrvatsku SS-diviziju (kasnije SS-divizija "Handžar"), pa je trebalo predložiti da i Muslimane, koje su uhapsili ili internirali Nijemci, također treba uputiti u tu diviziju. ${ }^{74}$

${ }^{71}$ HR-HDA-223, U. P. M. Taj. Broj: 209/1944.; HR-HDA-1197, Taj. Broj: 45/1944.

${ }^{72}$ Za primjerke letaka kojima su partizani pozivani da prebjegnu, a koje je izradila ispostava njemačke vojne propagande u Banja Luci vidi: National Archives and Records Service, Washington (NARA), T-314, Roll 564, snimke 404-409.

${ }^{73}$ NARA, T-314, Roll 564, snimke 363-364, Generalkommando XV. Geb. A. K, Abtl. Ic. Nr: 748/44 geh.

${ }^{74}$ HR-HDA-223, N. O. Broj: 3691/1943, Odsjek I. 
U januaru 1944. i vlasti NDH proglasile su amnestiju za partizane, odnosno one koji se nisu odazvali na službu u domobranstvo, ili su bili pripadnici domobranstva pa su prebjegli partizanima. Ova amnestija bila je na snazi do početka jula 1944. godine. One koji su se odazvali na amnestiju vlasti NDH ponovno su uvrštavale u svoje jedinice, ili su upućivani na rad u Njemačku. ${ }^{75}$

Aleksandar Benak je, kao glavar građanske uprave u Banja Luci, početkom februara 1944. posjetio njemački logor u tom gradu u kojem su bili smješteni partizanski prebjezi. Benak je među njima susreo i ljude s područja Bihaća, Cazina i Sanskoga Mosta. Oni su izjavljivali da su služili u domobranstvu i oružništvu, zatim su ih zarobili i u svoje redove mobilizirali partizani, a zatim su iz partizana prebjegli i predali se Nijemcima. Ti ljudi tražili su da ih se oslobodi, kako bi se ponovno mogli priključiti jedinicama NDH. ${ }^{76}$

Josip Brnčić, predstavnik Narodnooslobodilačkog pokreta zadužen za pregovore s Nijemcima oko razmjene zarobljenika, sredinom marta 1944. u jednom je izvještaju naveo da Nijemci teže što više zarobljenih partizana uputiti na rad u Njemačku. Tako Nijemci zarobljene partizane "u zadnje vrijeme redovno ne ubijaju", a puno se bolje ponašaju prema onim zarobljenicima koji se jave za odlazak na rad u Njemačku. ${ }^{77}$

Krajem maja 1944. ministar oružanih snaga, ustaški pukovnik Ante Vokić, u jednom je dopisu objasnio da između NDH i Nijemaca ne postoji dogovor o postupku s ratnim zarobljenicima. Nijemci odvode zarobljenike u svoje logore i zatim ih uglavnom šalju na rad u Njemačku. Uostalom, s Nijemcima je krajem 1943. dogovoreno da snage NDH sve zarobljene partizane predaju u njemačke zarobljeničke logore, a one su i sve prebjegle partizane također morale predati Nijemcima. Nakon što je NDH u januaru 1944. donijela vlastitu amnestiju za partizane, njezine su vlasti odredile da se Nijemcima predaju samo oni zarobljeni partizani, ili prebjezi iz redova partizana, koji

${ }^{75} \mathrm{~N}$. Barić, Ustroj kopnene vojske domobranstva NDH, 486-491.

${ }^{76}$ HR-HDA-223, U. P. M. Taj. Broj: 2030/1944.

${ }^{77}$ A. Miletić, Koncentracioni logor Jasenovac, Knjiga II, dok. br. 320. 
nisu pripadnici NDH, primjerice partizane koji su iz Crne Gore, Slovenije ili Srbije. U stvarnosti je stanje, kako je objasnio Vokić, bilo takvo da su Nijemci sve partizane koje su zarobili odvodili u svoje zarobljeničke logore, a isto su činili i s onima koje su zarobile jedinice NDH koje su bile pod njemačkim zapovjedništvom. Vokić je ocijenio da bi bilo potrebno da Vlada NDH s Nijemcima uredi pitanje postupka sa zarobljenim partizanima. ${ }^{78}$

Vlasti NDH, kako je opisano, nisu bile zadovoljne što Nijemci u nekim slučajevima "otimaju” i odvode na rad u Njemačku njezine državljane, a vidljivo je da nisu bile zadovoljne ni činjenicom da su Nijemci gotovo u cijelosti raspolagali zarobljenim partizanima. No, ovo je imalo i svoje naličje. Tako je u ljeto 1944. Poslanstvo NDH u Berlinu obavijestilo Zagreb da često prima molbe različitih vlasti NDH da se određene osobe oslobode iz Njemačke, ali su te osobe zapravo "djelatni komunisti ili bivši partizani” koji se, uostalom, niti ne žele vratiti u NDH, a ako bi se vratili nesumnjivo je da bi "vršili neželjenu djelatnost”. Nakon primitka ovih podataka o njima su obaviještene vlasti u cijeloj NDH s uputom da, u buduće, prilikom intervencije za oslobađanje određenih osoba iz Njemačke, barem "približno" saznaju o kakvim je osobama riječ. ${ }^{79}$

\section{Završna razmatranja}

$\mathrm{NDH}$, odnosno ustaški režim, svojom politikom, državnim terorom, progonom i ubijanjem srpskog stanovništva, ubrzo su izazvali ustanak i nastanak partizanskog i četničkog pokreta. NDH nije bila u stanju vlastitom vojnom silom ugušiti ustanak. Nakon toga je talijanska vojska (što nije predmet ovoga priloga) preuzela upravu u talijanskom interesnom području NDH, koji je uključivao i dijelove Bosne i Hercegovine. Nijemci su, postupno, počeli sve više sudjelovati u gušenju ustanka u NDH. Do početka 1943, paralelno s velikim operacijama osovinskih snaga protiv partizana

\footnotetext{
${ }^{78}$ HR-HDA-1549, III-45/16-18, NDH, Ministarstvo unutarnjih poslova, Glavno ravnateljstvo za javni red i sigurnost, Taj. Broj: 2605/1944.

${ }^{79}$ HR-HDA-1549, I-98/303, NDH, Ministarstvo unutarnjih poslova, Glavno ravnateljstvo za javni red i sigurnost, Tajničtvo glavnog ravnatelja, R. S. Taj. Broj: 2210/1944. Gl. r.
} 
u Bosni i Hercegovini, njemačka vojska je u cijelosti preuzela zapovijedanje nad snagama NDH, kao i kontrolu nad njezinom civilnom upravom.

Sve navedeno pokazivalo je slabost NDH i njezinu ovisnosti o Nijemcima. S druge strane, kako su Nijemci imali glavnu ulogu u borbi protiv partizana, oni su svojim represivnim mjerama pogađali i dijelove stanovništva koje je NDH smatrala lojalnima, a time je opet slabilo povjerenje tog stanovništva u NDH i njezine vlasti. O ovome je govorila i promemorija koje su vlasti NDH početkom 1944. uputile u Berlin. U njoj je navedeno da njemačke jedinice neprekidno vrše represalije, odnosno odmazde nad hrvatskim stanovništvom, što među "najširim slojevima" izaziva "dezorijentaciju” i "užasavanje”. Zato je zatraženo da se njemačke vojska, u mjeri u kojoj je moguće, uzdrži od takvih mjera koje stanovništvo dovodi do uznemirenosti koja šteti savezničkim odnosima NDH i Njemačke. ${ }^{80}$

Odnos vlasti NDH prema njemačkoj vojsci i njezinim represivnim mjerama, na zanimljiv je način opisan u jednom izvještaju njemačke vojne obavještajne službe iz aprila 1944. godine. U njemu je navedeno da se Ante Pavelić baca "u naručje" Njemačkoj, ali paralelno s ovime među funkcionerima NDH ne nedostaje neprijateljstva prema Nijemcima. Tako su ustaše vlastitu nepopularnost pred hrvatskim narodom prethodno težili "razvodniti”, kriveći za probleme prisutnost talijanske vojske u NDH. Nakon što je Italija u septembru 1943. kapitulirala, ustaše se na sličan način opravdavaju da su "nemoćni", budući da ionako o svemu odlučuju Nijemci. Pri tome je u tom njemačkom izvještaju posebno spomenut Vjekoslav Vrančić, koji je - kako sam naveo u ovom prilogu - vodio Ured pomoćnika ministra unutarnjih poslova NDH, zadužen za odnose s njemačkom vojskom. Njemački obavještajci naveli su da Vrančić na navedenoj dužnosti "vrijedno" prikuplja materijale koji će poslužiti kao optužnica protiv njemačke vojske, na sličan način na koji je Vrančić već pisao protiv talijanske vojske. ${ }^{81}$ Pri ovome se mislilo na to da je Vrančić, nakon talijanske kapitulacije, objavio

\footnotetext{
${ }^{80}$ B. Krizman, Ustaše i Treći Reich, Prvi svezak, 287-288.

${ }^{81}$ Karl Hnilicka, Das Ende auf dem Balkan 1944/45, Die militärische Räumung Jugoslaviens durch die deutsche Wehrmacht, Göttingen - Zürich - Frankfurt: Musterschmidt, 1970, 285.
} 
knjigu Urota protiv Hrvatske, u kojoj je oštro kritizirao prethodne postupke talijanske vojske u NDH i njezinu suradnju s četnicima. Očito su njemački vojni obavještajci smatrali da bi, u određenim okolnostima, Vrančić sličnu knjigu mogao napisati i o njemačkim postupcima u NDH.

Razumljivo, sve žalbe NDH na postupke njemačke vojske padale su u drugi plan pred činjenicom da je ustaški režim ovisio upravo o potpori te iste vojske. Također, dok su se vlasti NDH nerijetko žalile na postupke Nijemaca istovremeno su i same primjenjivale represivne mjere slične njemačkima, poput upućivanja u sabirne logore i odmazdi nad taocima. Razlika između NDH i Nijemaca bila je, rekao bih, u tome što su Nijemci bez oklijevanja bili spremni primijeniti represiju, odnosno veliko nasilje, kako bi suzbili Narodnooslobodilački pokret, ali ih istovremeno nisu zanimale "pristranosti” vlasti $\mathrm{NDH}$. To se vidi na navedenom primjeru da njemački general Lüters nije bio zadovoljan, kada su funkcioneri NDH zahtijevali da se kao taoci za odmazde uzmu isključivo Srbi, pa su Nijemci u svojim smjernicama isticali da taoce treba uzimati "bez obzira na narodnu pripadnost".

Također je zanimljiva njemačka promjena u odnosu prema partizanima prisutna od 1943. godine. Do tada su ih Nijemci smatrali "banditima” koje treba strijeljati na licu mjesta, ali su im zatim ipak bili spremni priznati status "ratnih zarobljenika" s ciljem da se i na taj način osigura radna snaga potrebna njemačkom gospodarstvu. Očito je na ovu promjenu utjecalo i širenja i jačanja Narodnooslobodilačkog pokreta, te je i Nijemcima postalo očito da represija i nasilje ne mogu biti isključivo rješenje za njegovo suzbijanja. Zato su od 1943. Nijemci i vodili propagandnu akciju kako bi partizane potaknuli na predaju. 


\section{IZVORI I LITERATURA}

Arhivski izvori

\section{Hrvatski državni arhiv, Zagreb}

HR-HDA-212, Predsjedništvo vlade NDH

HR-HDA-216, Ministarstvo narodne prosvjete NDH

HR-HDA-217, Ministarstvo narodnog gospodarstva NDH

HR-HDA-223, Ministarstvo unutarnjih poslova NDH

HR-HDA-254, Velika župa Posavje

HR-HDA-1197, Oružničko krilno zapovjedništvo Dubrovnik

HR-HDA-1198, Oružničko krilno zapovjedništvo Bileća

HR-HDA-1450, Zbirka mikrofilmova gradiva iz inozemnih arhiva koje se odnosi na Hrvatsku

HR-HDA-1549, Zbirka zapisa upravnih i vojnih vlasti NDH i Narodnooslobodilačkog pokreta

\section{Državni arhiv u Karlovcu}

HR-DAKA-348, Zbirka preslika iz Arhiva oružanih snaga (Vojno-istorijski institut) u Beogradu

Historijski muzej Bosne i Hercegovine, Sarajevo

Zbirka Ustaške nadzorne službe

\section{Objavljeni izvori}

Građa za povijest Narodnooslobodilačke borbe i socijalističke revolucije u sjeverozapadnoj Hrvatskoj 1941 -1945, Knjiga VI (rujan - listopad 1943), Zagreb, 1987.

Europa unterm Hakenkreuz. Die Okkupationspolitik des deutschen Faschismus (1938-1945), Achtbändige Dokumentenedition, Band 6, Die Okkupationspolitik des deutschen Faschismus in Jugoslawien, Griechenland, 
Albanien, Italien und Ungarn (1941-1945), Berlin-Heidelberg: Hüthig Verlagsgemeinschaft, 1992.

Miletić, Antun, Koncentracioni logor Jasenovac 1941-1945, Dokumenta, Knjiga II, Beograd-Jasenovac: Narodna knjiga, Spomen-područje Jasenovac, 1986.

National Archives and Records Service, Washington. Records of German Field Commands, Microcopy T-314, Roll 564, 1962.

Nezavisna Država Hrvatska, Zakoni, zakonske odredbe, naredbe i t. d. proglašene od 23. listopada do 27. studenoga 1943, Knjiga XXXIX. (svezak 381.-390.), Uređuje: A. Mataić, Zagreb: Knjižara St. Kugli, 1943.

Vojnoizdavački zavod "Vojno delo"/Vojnoistorijski institut, Zbornik dokumenata i podataka o Narodnooslobodilačkom ratu jugoslovenskih naroda, Tom IV, knjige 9, 10, 11, 15, 16, 18, Borbe u Bosni i Hercegovini 1943 god, Beograd, 1954-1958.

Vojnoistorijski institut, Zbornik dokumenata i podataka o Narodnooslobodilačkom ratu naroda Jugoslavije, Tom XII, knjige 1-3, Dokumenti Nemačkog Rajha, Beograd, 1973-1978.

\section{Literatura}

\section{Knjige}

Barić, Nikica, Ustroj kopnene vojske domobranstva Nezavisne Države Hrvatske, 1941.-1945, Zagreb: Hrvatski institut za povijest, 2003.

Dulić, Tomislav, Utopias of Nation, Local Mass Killing in Bosnia and Herzegovina, 1941-42, Uppsala: Acta Universitatis Upsaliensis, 2005.

Hnilicka, Karl, Das Ende auf dem Balkan 1944/45, Die militärische Räumung Jugoslaviens durch die deutsche Wehrmacht, Göttingen - Zürich - Frankfurt: Musterschmidt, 1970.

Hodžić, Sanela, Schölzel, Christian, Zwangsarbeit und der Unbhängige Staat Kroatien 1941 - 1945, Berlin-Münster: Lit Verlag Dr. W. Hopf, 2013.

Hurem, Rasim, Bosna i Hercegovina u Drugom svjetskom ratu 1941-1945, 
Zagreb-Sarajevo: Plejada - Bošnjačka nacionalna zajednica za Zagreb i Zagrebačku županiju - University Press, 2016.

Krizman, Bogdan, Ustaše i Treći Reich, Prvi svezak, Zagreb: Globus, 1983.

\section{Članci}

Barić, Nikica, "Kozara 1942. - sudbina zarobljenika, civila i djece”, u: Pilar, Časopis za društvene i humanističke studije, br. 22(2), Zagreb: Institut društvenih znanosti Ivo Pilar, 2016, 53-111.

Barić, Nikica, "Njemačka 1. kozačka divizija u Slavoniji tijekom Drugoga svjetskog rata", u: Scrinia Slavonica, Godišnjak Podružnice za povijest Slavonije, Srijema i Baranje Hrvatskog instituta za povijest, Vol. 18, Slavonski Brod, 2018, 373-403.

Brčić, Rafael, "Njemački i italijanski planovi u Bosni i Hercegovini u svjetlu dokumenata (1942-1943), AVNOJ i Narodnooslobodilačka borba u Bosni i Hercegovini (1942-1943), Materijali sa naučnog skupa održanog u Sarajevu 22. i 23. novembra 1973. godine, Urednik: Dušan Papadopolos, Beograd: "Rad", 1974, 131-155.

Брчић, Рафаел, “Основна обиљежја корекције њемачко-усташке политике према Србима у «Независној Држави Хрватској», u: Прилози, Година XI-XII, Број 11-12, Сарајево: Институт за историју, 1975-1976, 177-206.

Gumz, Jonathan E. "Wehrmacht Perceptions of Mass Violence in Croatia, 1941-1942”, u: The Historical Journal, Cambridge, Volume 44, 4, 2001, 1015-1038.

Kobsa, Leopold, "O organizaciji ustaškog aparata vlasti za provođenje terora u tzv. NDH”, u: Zagreb u NOB-i i socijalističkoj revoluciji, Materijali sa znanstvenog skupa održanog u Zagrebu 29. i 30. lipnja 1970. u povodu 25. godišnjice oslobođenja grada Zagreba, Zagreb: Institut za historiju radničkog pokreta Hrvatske, 1971, 223-251.

Schmider, Klaus, Auf Umwegen zum Vernichtungskrieg? Der Partisanenkrieg in Jugoslawien, 1941-1944.", u: Die Wehrmacht, Mythos und Realität, Im 
Auftrag des Militärgeschichtlichen Forschungsamtes herausgegeben von Rolf-Dieter Müller und Hans-Erich Volkmann, München: R. Oldenbourg Verlag, 1999, 901-922.

Srpak, Nikolina, "Kazneno pravo u doba Nezavisne Države Hrvatske (1941.1945.)", u: Hrvatski ljetopis za kazneno pravo i praksu, Zagreb: Hrvatsko udruženje za kaznene znanosti i praksu, Vol. 13, br. 2, 2006, 1117-1144.

Stojanović, Vlado, “Zbjegovi naroda na područjima zahvaćenim operacijama 'Weiss' i 'Schwarz' 1943. godine”, u: Zbornik radova naučnog skupa "Neretva - Sutjeska 1943” održanog od 27. juna do 2. jula 1968. god. u Sarajevu, Odgovorni urednik: Branko Borojević, Beograd: Vojnoistorijski institut, 1969, 286-292. 


\title{
REPRESSIVE MEASURES OF THE WEHRMACHT IN BOSNIA AND HERZEGOVINA DURING WORLD WAR TWO
}

\begin{abstract}
Summary
The paper presents the main elements of repressive measures used by the German Wehrmacht in Bosnia and Herzegovina during World War II. In that period Bosnia and Herzegovina was part of the Independent State of Croatia (Nezavisna Država Hrvatska, NDH) ruled by the Ustasha regime, allied to Hitler's Germany and Mussolini's Italy. Bosnia and Herzegovina soon became the main area of operations of the People's Liberation Movement led by the Communist Party of Yugoslavia and its Partisan units. As NDH troops became unable to suppress the uprising, the Wehrmacht gradually took the increasing role and ultimately gained command and control over NDH troops and civilian authorities. In order to destroy the People's Liberation Movement, Germans used a variety of repressive measures: the shooting of captured Partisans and suspicious civilians, reprisal executions of civilians, and deportations of captured Partisans and civilians to German Reich, where they were used as (forced) labour. Initially, the Wehrmacht perceived Partisans as "bandits" and they were to be shot on the spot. This changed from 1943 when it was decided that captured Partisans should be treated as "prisoners of war" in order to send them to Germany as a labour force. Also in 1943 the Wehrmacht initiated a propaganda campaign in order to encourage Partisans to defect and surrender. The paper also shows how Wehrmacht's reprisal measures affected the relations between the Wehrmacht and NDH authorities.
\end{abstract}

